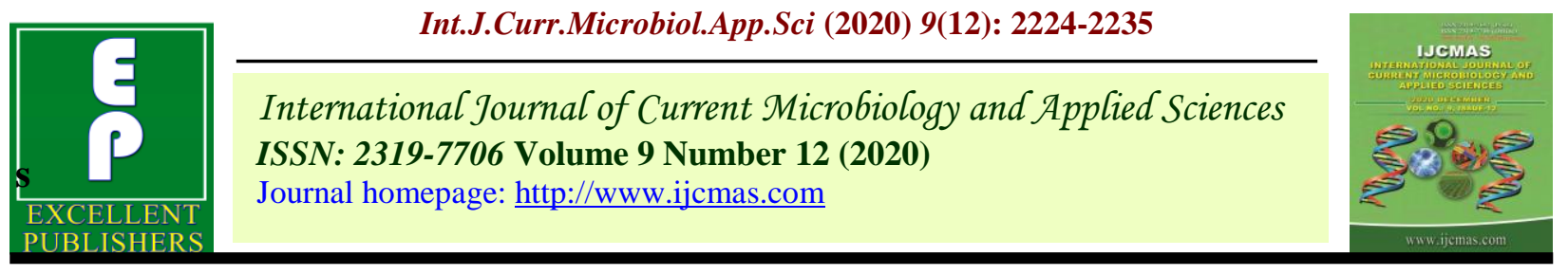

Original Research Article

https://doi.org/10.20546/ijcmas.2020.912.262

\title{
Diversification of Agricultural Crops in Himachal Pradesh: A Shift towards High-Value Crops
}

\author{
Jyoti Chaudhary* and H. P. Singh \\ Department of Agricultural Economics, Institute of Agricultural Sciences, \\ BHU, Varanasi, Uttar Pradesh, India \\ *Corresponding author
}

\begin{tabular}{|c|c|}
\hline & A B S T R A C T \\
\hline & \multirow{4}{*}{$\begin{array}{l}\text { During the last few decades, the agricultural diversification in Himachal Pradesh } \\
\text { towards high-value crops i.e. fruits and vegetables including off-season vegetables } \\
\text { have increased at a fast rate. The process of diversification has started in the late } \\
\text { sixties and picked up pace in the eighties after that the state has made reasonable } \\
\text { progress. This paper has studied the growth in the area, production, and } \\
\text { productivity of all foodgrains and non-foodgrains for over three decades. The } \\
\text { analysis brings out a shift in the cropping pattern of agricultural commodities as } \\
\text { the area under foodgrains declined and increased in the area under high-value } \\
\text { commodities in the state. The districts with the favourable agroclimatic conditions } \\
\text { shifted from cereal-based cropping patterns towards temperate fruits and vegetable } \\
\text { (temperate) production at the commercial level. }\end{array}$} \\
\hline $\begin{array}{l}\text { Diversification, } \\
\text { Off-season } \\
\text { vegetables, High- } \\
\text { value commodities, } \\
\text { Cropping pattern }\end{array}$ & \\
\hline Article Info & \\
\hline $\begin{array}{l}\text { Accepted: } \\
\text { 16 November } 2020 \\
\text { Available Online: } \\
10 \text { December } 2020\end{array}$ & \\
\hline
\end{tabular}

\section{Introduction}

Diversification is an essential component of the structural transformation of an economy. India is an agrarian economy so as the state Himachal Pradesh and shares about1.7 per cent area in the total geographical area of the country. The state is in the northern part of India, situated in the western Himalayas. It is a small mountainous state with a total geographical area of 55,673 sq. $\mathrm{Km}$ and the altitude range from $350 \mathrm{~m}$ to $6975 \mathrm{~m}$ above mean sea level which is one among the reasons for diverse agroclimatic conditions in the state. Agriculture is the main source of income and about 12.73 per cent of total GSDP comes from agriculture and allied sectors. More than 85 per cent of the population depends upon agriculture for their livelihood, and about 87 per cent being marginal and small farmers owning average landholdings of 1.8 hectares accounts for about 54 per cent area and only 0.34 per cent by large farmers. Thus, the agriculture in mountainous region is circumscribed by specificities like, marginality, inaccessibility, niche and human adaptation mechanism prevail due to vertical dimension that 
distinguishes them from plains and another ecosystem. The agriculture in hilly areas was always featured as cereal-based and characterized by low and stagnant productivity. But with the introduction of the high-value cash crops and high yielding varieties in the production system, the production pattern has shifted from traditional subsistence-oriented, cereal-based agriculture to high-value cash crops based commercial agriculture.

Over the decades the contribution of the agriculture and allied sectors in gross state domestic product has declined from 57.9 per cent in 1950-51 to 55.5 per cent in 1967-68, 26.5 per cent $1990-91$ and to 8.4 per cent in 2018-19 as it shifted to industrial and services (Economic Survey of HP, 2019-20). Despite declining share, the importance of the agriculture sector does not affect, as its major contributor in total domestic product and also its contribution to other sectors via input linkages, employment, trade, and transportation. Since the early 1970s, this sector has made considerable progress, as is evident from an increase in foodgrain production from 9.45 lakh tonnes in 1972-73 to lakh tonnes in 15.81 lakh metric tonnes 2017-18and 16.92 lakh metric tonnes in 201819(Sharma and Chauhan, 2013). The productivity of different crops has also increased but the important transformation has been the diversification of agriculture towards high-value cash crops, including fruits and vegetables (off-season) which was the main policy thrust in Himachal Pradesh since it attained the statehood in 1971. The process of diversification towards fruits and vegetables started in the late fifties and sixties in the districts of Shimla, Kullu, Solan, and Lahaul \& Spiti which extended in late seventies and eighties to other parts and gained momentum in the nineties when the process spread even to low and mid-hill districts (Sharma, 2011).The crop diversification towards high-value cash cropbased commercial agriculture promotes the productive use of abundant small and marginal lands $(54 \%)$ in these regions. It also helps in maintaining and improving the ecology and environment by promoting soil conservation and improving soil fertility (Kumari, 20007). Further, the diversification of agriculture with high-value off-season vegetable crops has made a noticeable impact on the standard of living and quality of life of rural people (Sharma and Chauhan, 2008). Thus, keeping this in view the present study has been conducted to study the growth in the area production and productivity of various agricultural commodities and the extent of diversification in agriculture over the years.

\section{Materials and Methods}

For this study, thetime series data regarding the area, production, and productivity of various agricultural commodities have been collected. The data germane to the study was collected from the various publications of the state government and records from different departments like Department of Agriculture, Directorate of Horticulture and the Directorates of Land Records for all the 12 districts of the state namely Bilaspur, Chamba, Hamirpur, Kangra, Kinnaur, Kullu, Lahaul\& Spiti, Mandi, Shimla, Sirmaur, Solan and Una. The data is collected for the year 1991-92 to 2017-18. The data were analysed using appropriate tools like tabular analysis, using average and percentages. The extent of crop diversification has been studied by analysing temporal changes in the cropping pattern, the area under fruit and vegetable crops. The Simpson Index of Diversification used to compute crop diversity in the districts and state as a whole. A zero (0) value of SID indicates specialization and its value approaches one (1) with an increase in the extent of diversification. 
$\mathrm{SID}=1-\sum_{\mathrm{i}=1}^{\mathrm{n}}\left(\frac{A i}{G C A}\right)^{2}$

Where, $\mathrm{Ai}=$ Area under $\mathrm{i}^{\text {th }}$ crop, GCA $=$ Gross cropped area

Compound growth rates (CAGR) of area, production, and yield of crops were estimated as:

$Y_{t}=A B^{t}$

Where, $Y_{t}=$ area/ production/ yield of major crops in $\mathrm{t}^{\text {th }}$ period

$\mathrm{t}=$ time variable $(1,2,3 \ldots, \mathrm{n})$,

$\mathrm{A}=$ constant,

$\mathrm{B}=$ regression coefficient of $\mathrm{Y}$ on time $\mathrm{t}$

After $\log$ transformation and estimation of the above function as $\ln \mathrm{Y}_{\mathrm{t}}=\ln \mathrm{A}+\mathrm{t} \ln \mathrm{B}$, compound growth rate will be estimated as:

$r=(\operatorname{antilog} B-1)^{X_{100}}$

Instability was estimated using the Coefficient of variation as follows:

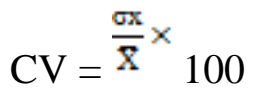

Where, $\sigma_{X}=$ standard deviation of $X$

$\bar{X}=$ mean of $\mathrm{X}$

$\mathrm{X}=$ area/ production/ yield

\section{Results and Discussion}

The cropping pattern in Himachal Pradesh is examined for all the districts looking at the share of individual crop area in the gross cropped area (GCA). It also indicates the extent of the intensification of agriculture. Table 1 shows that the two crops namely wheat and maize occupied around 67.19 per cent of GCA during TE 2016-17 which was 71.73 per cent during 1991-92. Wheat is the major staple crop of Himachal Pradesh and maize is second in place after wheat. But over the years the share of area under rice, wheat, and maize has declined steadily. The area share of area under pulses has also declined drastically from 4.18 per cent (1991-92) to 2.80 per cent (2016-17). Hence the share of area under total foodgrains has declined from $88.82 \%$ to $81.71 \%$ during the study period. This decline in area under foodgrains might be happened due to a shift in production pattern from traditional cereals-based cropping pattern towards high-value crops and off-season vegetables. The share of area under foodgrains has fallen in almost all the districts except few and the maximum decline in the area is in Kinnaur, Kullu, Lahaul and Spiti, Shimla and Sirmaur. The share of vegetables has increased from 2.75 per cent to 4.53 per cent and for fruits from 4.30 per cent to 10.52 per cent during the study period. the maximum increase in the share of area under vegetables is in Lahaul and Spiti $(58.80 \%$ during 2016-17) followed by Sirmaur, Kinnaur and Kullu over the years the area under spices has increased in Sirmaur where the crops like ginger cultivation have taken place in recent years. Therefore, the decrease in the area under rice, wheat, maize, barley and other cereals, pulses and increase in the area under vegetable and fruit crops shown the process of diversification (Sharma, 2011).

\section{Crop diversification in the state}

To see the extent of diversification in the state the Simpson Index of Diversification has used. Table 2 shows that in the state crop diversification has taken place and the value of the index has increased all over the period from 0.727 during $1991-92$ to 0.740 during 2001-02 which further increased to 0.757 during 2017-18 (Singh, 2006; Krishan, 2014). Thus, in the state as a whole, the diversification has taken place, but at the district level, the mixed result has been found in the diversification. During 1991-92 except 
Bilaspur, Hamirpur, Una all other districts have high diversification index ranging from 0.704 to 0.835 . Districts like Chamba, Kullu, Sirmaur are moving towards diversification during 2017-18. While, Bilaspur, Hamirpur, Kangra, Solan, and Una has shown a decline in the diversification index over the three decades. During the 1990s Lahaul Spiti moved towards diversification similarly and started moving towards specialization during 2001-02 and 2011-12 and further during 2017-18 showed a shift towards diversification. The District Kinnaur and Lahaul and Spiti which are tribal districts shifted towards fruits and vegetable production from foodgrains which led to specialization as shown by cropping pattern also and a decline is seen in diversification index from 0.820 to 0.663 for Kinnaur and 0.835 to 0.606 for Lahaul and Spiti.

\section{Temporal changes in area, production and productivity of cereals}

Cereals play a major role in providing food security. Rice, wheat, and maize are the major cereals consumed by the population in Himachal Pradesh. The temporal changes in the area production and productivity of cereals presented in Table 3. The area under cereals is maximum in Kangra which is the largest district area-wise, followed by Mandi districts during 1991-92 and 2017-18. Over the years the area under cereals has shown a mild decline. The maximum decline in area under cereals was in Shimla (58\%) followed by Lahaul \& Spiti (56\%) and Kinnaur (56 \%). The production of cereals has increased over the years from 1263.88 thousand tonnes to 1366.95 thousand tonnes in the states, Kangra being the largest producer of the cereals in the state. Over three decades the production of cereals has increased by $28 \%$ in the Chamba and decreased drastically in theLahaul-Spiti (84\%), Kinnaur (57\%), Shimla (50\%), Mandi (38\%), Sirmaur (21\%) and Hamirpur (16\%).
The productivity of the cereals in the state has increased from $1.53 \mathrm{t} / \mathrm{ha}$ to $1.94 \mathrm{t} / \mathrm{ha}$.

Temporal changes in area, production and productivity of pulses

Pulses are among major foodgrains that constitute important foodstuff for hilly people. The major pulses grown in the state are gram, black gram, horse gram, green gram. Table 4 tells the changing levels of the area, production, and productivity of pulses in different districts of the state. The area under pulses has nosedived from 40.91thousandhectares during TE 1991-92 to 25.95 thousand hectares during TE 2017-18 with a decline of around 36 per cent.

A proportionate decrease in the cultivation of pulses has been seen during 1991-92 to 201718 in almost all the districts. Kangra accounts for the maximum area under pulses but over the years it has declined by 37 per cent and the maximum decline in the area has been occurred in the district Hamirpur (97 \%), followed by Bilaspur (89\%) and Kinnaur (51 $\%)$. The production of the pulses is highest in Mandi district followed by Shimla, Sirmaur, and Chamba. Over three decades, the production of the pulses in Himachal Pradesh has increased by about $240 \%$. The maximum increase in production was observed in Chamba (654\%) followed by Kullu (483\%), Shimla (405\%) and Sirmaur (326 \%). The increase in production may be due to the introduction of high yielding varieties. Further, the increase in production led to the rise in the yield of the pulses from0.29 t/ha to $1.48 \mathrm{t} / \mathrm{ha}$ over the years.

\section{Temporal changes in area, production and productivity of fruits}

Over the past few decades, the state has made significant progress in the development of horticulture as shifted the cultivation pattern 
from cereal-based farming towards high-value commodities due to topographical variations and altitudinal differences along with fertile and well-drained soils suitable for the cultivation of temperate to sub-tropical fruits.

The total area under fruits is 228.95 thousand hectares during TE 2017-18 which has shown a proportionate increase of about $40 \%$ over the period (Table 5). The area under fruits during 2017-18 is maximum in Shimla (47.19 '000 ha) followed by Kangra, Mandi and Kullu. The area under the fruit crops has increased in almost all the districts between 1991-92 to 2017-18 and the maximum increase was in district Lahaul-Spiti (774 \%) followed by Kinnaur (125\%).

The production of fruits has increased by 77 $\%$ over 27 years. Shimla is the largest producer of the fruits (2017-18) as half of the fruit production in the state comes from this district followed by Kullu (8\%), Kinnaur (9 $\%)$ and Mandi (7\%). These four districts have a maximum contribution to apple production. The productivity of fruits is increased to 3.07 t/ha during 2017-18 from 2.44 t/ha. the productivity of fruits is maximum in Shimla (22.89 t/ha). Since the tribal districts Lahaul and Spiti and Kinnaur, most of the areas of Shimla, Kullu and Chamba and some areas of Sirmaur, Solan and Mandi that falls under the temperate region and thus have potential to grow temperate fruits.

\section{Temporal changes in area, production and productivity of vegetables}

Vegetable cultivation has led the state towards the diversification over the last few decades. The cultivation of the off-season vegetables helped the producers in the improvement of the quality of life in rural areas. Table 6 showed the area under vegetables has increased from 32.05 thousand ha to 76.95 thousand ha from TE 2001-02 to
TE 2017-18. Like fruits, Shimla has the largest area under vegetables. But over the two decades, the area has increased maximum in Hamirpur followed by Kinnaur. The production of vegetables was highest in Solan, followed by Shimla. The maximum increase in the production of the vegetables is in Mandi (351.71\%) followed by Hamirpur (332.97\%), Kangra (312.03\%) and Chamba $(243.54 \%)$. The productivity of vegetables in the state has increased from 17.97 t/ha (TE 2001-02) to 21.46 t/ha (TE 2017-18).

\section{Growth in the area, Production and Productivity of cereals}

The growth in the area under the cereals (Table 7) in the state has recorded a mild annual significant decrease of $0.51 \%$, among districts, it has shown significantly declined maximum in the Kinnaur (-4.00\%), followed by the Shimla and Lahaul \& Spiti with a decline of $-3.86 \%$ and $-3.53 \%$ respectively. The fluctuation in the area under cereals in the state is low (4.49\%) and in Shimla, Kinnaur and Lahaul \& Spiti the fluctuation is found high i.e. $32.02 \%, 31.90 \%$ and 28.35 $\%$, respectively due to varying climatic conditions.

Similarly, the growth rate of production in the state is negative and non-significant $(-0.12$ $\%)$. The growth rate of production in districts is positive and non-significant in half of the districts and negative in other i.e. Hamirpur, Kinnaur, Lahaul and Spiti Mandi, Shimla and Sirmaur.

The state has registered an annual increment of $0.39 \%$ in the productivity of the cereals with fluctuation of $11.97 \%$. The growth in the productivity of cereals in almost all the districts was positive but non-significant except in Lahaul \& Spiti (-3.76\%) and Mandi $(-2.55 \%)$. 
Table.1 District wise cropping pattern of Himachal Pradesh (1991-92 to 2016-17)

\begin{tabular}{|c|c|c|c|c|c|c|c|c|c|c|c|c|c|c|}
\hline Crop & Year & Bilaspur & Chamba & Hamirpur & Kangra & Kinnaur & Kullu & $\begin{array}{l}\text { Lahaul } \\
\text { \& Spiti }\end{array}$ & Mandi & Shimla & Sirmaur & Solan & Una & HP \\
\hline \multirow[t]{2}{*}{ Rice } & 1991-92 & 4.82 & 4.62 & 4.53 & 17.29 & 0.24 & 4.00 & 0.00 & 13.71 & 3.48 & 6.28 & 5.77 & 2.14 & 8.75 \\
\hline & 2016-17 & 2.31 & 4.77 & 2.37 & 17.91 & 0.06 & 1.17 & 0.00 & 11.03 & 0.72 & 9.84 & 6.95 & 2.12 & 8.16 \\
\hline \multirow[t]{2}{*}{ Wheat } & 1991-92 & 44.38 & 30.03 & 47.28 & 42.15 & 8.38 & 34.68 & 8.02 & 41.16 & 27.40 & 37.72 & 35.40 & 43.58 & 39.48 \\
\hline & 2016-17 & 45.38 & 33.16 & 46.63 & 45.57 & 1.44 & 21.33 & 1.56 & 41.60 & 9.22 & 33.53 & 41.71 & 46.94 & 37.37 \\
\hline \multirow{2}{*}{ Maize } & 1991-92 & 43.58 & 43.26 & 45.54 & 26.52 & 5.30 & 28.66 & 1.01 & 29.94 & 19.69 & 32.95 & 37.78 & 42.39 & 32.25 \\
\hline & 2016-17 & 50.54 & 38.75 & 49.54 & 23.86 & 0.58 & 25.45 & 0.33 & 29.65 & 7.90 & 24.10 & 35.49 & 40.92 & 29.82 \\
\hline \multirow[t]{2}{*}{ Barley } & 1991-92 & 0.77 & 6.19 & 0.25 & 1.52 & 17.76 & 5.80 & 23.35 & 2.66 & 5.11 & 3.67 & 2.85 & 0.08 & 2.93 \\
\hline & 2016-17 & 0.42 & 6.78 & 0.12 & 1.08 & 6.45 & 3.87 & 10.15 & 2.19 & 2.99 & 3.06 & 2.87 & 0.00 & 2.22 \\
\hline \multirow[t]{2}{*}{ Pulses } & 1991-92 & 2.71 & 5.52 & 1.46 & 2.72 & 10.67 & 6.18 & 27.16 & 2.79 & 6.47 & 5.75 & 7.21 & 2.97 & 4.18 \\
\hline & 2016-17 & 0.11 & 4.96 & 0.01 & 1.15 & 8.42 & 6.93 & 20.80 & 5.20 & 3.06 & 1.98 & 3.19 & 0.19 & 2.80 \\
\hline \multirow{2}{*}{$\begin{array}{l}\text { Total } \\
\text { foodgrains }\end{array}$} & 1991-92 & 96.27 & 92.64 & 99.07 & 90.28 & 75.43 & 83.51 & 62.55 & 92.41 & 71.04 & 87.78 & 89.02 & 91.16 & 88.82 \\
\hline & 2016-17 & 98.76 & 90.07 & 98.66 & 89.80 & 32.00 & 59.43 & 33.51 & 90.35 & 26.01 & 73.02 & 90.30 & 90.18 & 81.12 \\
\hline \multirow[t]{2}{*}{ Vegetables } & 1991-92 & 0.78 & 1.11 & 0.21 & 0.95 & 4.13 & 3.36 & 32.17 & 2.60 & 9.48 & 2.84 & 3.61 & 1.03 & 2.75 \\
\hline & 2016-17 & 0.44 & 2.88 & 0.37 & 1.54 & 9.39 & 7.48 & 58.80 & 4.05 & 10.58 & 11.34 & 4.27 & 2.85 & 4.53 \\
\hline \multirow[t]{2}{*}{ Fruits } & 1991-92 & 0.63 & 2.13 & 0.03 & 1.60 & 19.66 & 11.45 & 0.43 & 3.35 & 18.44 & 1.99 & 1.06 & 0.32 & 4.30 \\
\hline & 2016-17 & 0.29 & 5.85 & 0.13 & 3.29 & 57.88 & 30.00 & 5.69 & 4.22 & 62.45 & 2.21 & 0.43 & 0.61 & 10.52 \\
\hline \multirow[t]{2}{*}{ Oilseeds } & $1991-92$ & 1.64 & 3.96 & 0.32 & 4.56 & 0.33 & 1.16 & 0.29 & 0.58 & 0.66 & 1.63 & 3.07 & 3.42 & 2.22 \\
\hline & 2016-17 & 0.17 & 0.83 & 0.14 & 2.13 & 0.00 & 0.73 & 0.38 & 0.42 & 0.33 & 1.92 & 1.32 & 2.20 & 1.13 \\
\hline \multirow[t]{2}{*}{ Spice } & 1991-92 & 0.25 & 0.16 & 0.04 & 0.04 & 0.17 & 0.28 & 0.00 & 0.15 & 0.34 & 2.01 & 0.36 & 0.07 & 0.31 \\
\hline & 2016-17 & 0.34 & 0.27 & 0.14 & 0.06 & 0.54 & 2.31 & 0.00 & 0.34 & 0.58 & 7.24 & 2.86 & 0.08 & 1.08 \\
\hline \multirow[t]{2}{*}{ Others } & 1991-92 & 0.43 & 0.00 & 0.32 & 2.59 & 0.28 & 0.24 & 4.56 & 1.14 & 0.05 & 3.75 & 2.88 & 4.01 & 0.62 \\
\hline & 2016-17 & 0.00 & 0.10 & 0.55 & 3.18 & 0.19 & 0.04 & 1.63 & 0.62 & 0.04 & 4.27 & 0.81 & 4.08 & 1.61 \\
\hline \multicolumn{15}{|c|}{ Source: Directorate of Land Records, Shimla } \\
\hline
\end{tabular}


Table.2 Changing levels of crop diversification Indices (Simpson) across districts in Himachal Pradesh: 1991-92 to 2017-18

\begin{tabular}{|l|c|c|c|c|}
\hline Districts & $\mathbf{1 9 9 1 - 9 2}$ & $\mathbf{2 0 0 1 - 0 2}$ & $\mathbf{2 0 1 1 - 1 2}$ & $\mathbf{2 0 1 7 - 1 8}$ \\
\hline Bilaspur & 0.599 & 0.567 & 0.558 & 0.538 \\
\hline Chamba & 0.713 & 0.722 & 0.726 & 0.729 \\
\hline Hamirpur & 0.564 & 0.544 & 0.534 & 0.532 \\
\hline Kangra & 0.707 & 0.697 & 0.689 & 0.690 \\
\hline Kinnaur & 0.820 & 0.842 & 0.755 & 0.663 \\
\hline Kullu & 0.775 & 0.787 & 0.790 & 0.826 \\
\hline Lahaul \& Spiti & 0.751 & 0.685 & 0.665 & 0.709 \\
\hline Mandi & 0.711 & 0.718 & 0.712 & 0.717 \\
\hline Shimla & 0.835 & 0.840 & 0.733 & 0.606 \\
\hline Sirmaur & 0.725 & 0.756 & 0.773 & 0.790 \\
\hline Solan & 0.704 & 0.697 & 0.679 & 0.686 \\
\hline Una & 0.600 & 0.616 & 0.579 & 0.579 \\
\hline Hp & 0.727 & 0.740 & 0.736 & 0.757 \\
\hline
\end{tabular}

Source: Directorate of Land Records, Shimla

Table.3 Area, production and productivity of cereals (1991-92 to 2017-18)

\begin{tabular}{|l|c|c|c|c|c|c|}
\hline & \multicolumn{2}{|c|}{ Area ('000 ha) } & \multicolumn{2}{c|}{$\begin{array}{c}\text { Production ('000 Metric } \\
\text { tonnes) }\end{array}$} & \multicolumn{2}{c|}{ Productivity (t/ha) } \\
\hline & $\begin{array}{c}\text { TE 1991- } \\
92\end{array}$ & $\begin{array}{c}\text { TE 2017- } \\
18\end{array}$ & TE 1991-92 & TE 2017-18 & TE 1991- & TE 2017- \\
& 56.10 & 49.31 & 90.95 & 93.68 & 1.62 & 1.89 \\
\hline Bilaspur & 56.33 & 51.90 & 105.52 & 135.77 & 1.87 & 2.61 \\
\hline Chamba & 73.76 & 61.69 & 121.09 & 101.41 & 1.64 & 1.64 \\
\hline Hamirpur & 187.49 & 178.17 & 296.69 & 323.56 & 1.58 & 1.81 \\
\hline Kangra & 5.79 & 2.55 & 5.14 & 2.22 & 0.89 & 0.86 \\
\hline Kinnaur & 46.74 & 40.71 & 88.46 & 88.71 & 1.90 & 2.18 \\
\hline Kullu & 1.17 & 0.51 & 1.52 & .25 & 1.30 & 0.48 \\
\hline Lahaul \& Spiti & 148.17 & 128.72 & 228.81 & 141.42 & 1.54 & 1.10 \\
\hline Mandi & 70.46 & 29.51 & 110.41 & 55.51 & 1.57 & 1.85 \\
\hline Shimla & 64.48 & 53.73 & 127.99 & 101.34 & 1.99 & 1.88 \\
\hline Sirmaur & 55.89 & 52.07 & 98.85 & 107.56 & 1.76 & 2.06 \\
\hline Solan & 61.72 & 60.11 & 94.78 & 108.92 & 1.53 & 1.80 \\
\hline Una & 828.11 & 708.96 & 1263.88 & 1366.95 & 1.53 & 1.94 \\
\hline HP & & & & & \\
\hline
\end{tabular}

Source: Directorate of Land Records, Shimla 
Table.4 Area, production and productivity of pulses (1991-92 to 2017-18)

\begin{tabular}{|l|c|c|c|c|c|c|}
\hline & \multicolumn{2}{|c|}{ Area ('000 ha) } & \multicolumn{2}{c|}{$\begin{array}{c}\text { Production ('000 Metric } \\
\text { tonnes) }\end{array}$} & \multicolumn{2}{c|}{\begin{tabular}{c} 
Productivity (t/ha) \\
\hline
\end{tabular}} \\
\hline TE $1991-92$ & TE $2017-18$ & TE 1991-92 & TE 2017-18 & TE 1991-92 & TE 2017-18 \\
\hline Bilaspur & 1.62 & 0.17 & 0.73 & 0.11 & 0.47 & 0.65 \\
\hline Chamba & 3.57 & 3.44 & 0.86 & 6.51 & 0.24 & 1.64 \\
\hline Hamirpur & 1.10 & 0.02 & 0.26 & 0.01 & 0.25 & 0.31 \\
\hline Kangra & 5.83 & 3.64 & 1.80 & 5.66 & 0.31 & 1.41 \\
\hline Kinnaur & 0.95 & 0.47 & 0.26 & 0.69 & 0.27 & 1.65 \\
\hline Kullu & 3.74 & 2.68 & 0.86 & 5.00 & 0.23 & 1.56 \\
\hline Lahaul \& Spiti & 0.90 & 0.69 & 0.95 & 0.82 & 1.07 & 1.69 \\
\hline Mandi & 4.61 & 4.42 & 1.77 & 6.93 & 0.38 & 1.55 \\
\hline Shimla & 7.06 & 4.58 & 1.35 & 6.84 & 0.19 & 1.36 \\
\hline Sirmaur & 4.52 & 3.93 & 1.60 & 6.81 & 0.35 & 1.61 \\
\hline Solan & 4.93 & 1.73 & 0.95 & 1.45 & 0.20 & 0.83 \\
\hline Una & 2.08 & 0.17 & 0.66 & 0.12 & 0.32 & 0.74 \\
\hline HP & 40.91 & 25.95 & 12.03 & 40.94 & 0.29 & 1.48 \\
\hline
\end{tabular}

Source: Directorate of Land Records, Shimla

Table.5 Area, production and productivity of fruits (1991-92 to 2017-18)

\begin{tabular}{|l|c|c|c|c|c|c|}
\hline \multirow{2}{*}{} & \multicolumn{2}{|c|}{ Area ('000 ha) } & \multicolumn{2}{c|}{$\begin{array}{c}\text { Production (‘000 Metric } \\
\text { tonnes) }\end{array}$} & \multicolumn{2}{c|}{ Productivity (t/ha) } \\
\cline { 2 - 7 } & TE $1991-92$ & TE 2017-18 & TE $1991-92$ & TE 2017-18 & TE 1991-92 & TE 2017-18 \\
\hline Bilaspur & 6.56 & 7.98 & 1.09 & 3.45 & 0.17 & 0.43 \\
\hline Chamba & 8.52 & 16.97 & 4.60 & 21.88 & 0.54 & 1.29 \\
\hline Hamirpur & 4.39 & 7.55 & 1.07 & 3.45 & 0.25 & 0.46 \\
\hline Kangra & 34.68 & 40.20 & 14.66 & 44.82 & 0.43 & 1.12 \\
\hline Kinnaur & 5.76 & 12.97 & 13.00 & 63.14 & 2.25 & 4.87 \\
\hline Kullu & 19.78 & 30.33 & 97.20 & 127.83 & 4.94 & 4.23 \\
\hline Lahaul \& Spiti & 0.20 & 1.76 & 0.05 & 0.33 & 0.28 & 0.19 \\
\hline Mandi & 24.85 & 37.07 & 16.46 & 50.72 & 0.67 & 1.37 \\
\hline Shimla & 30.59 & 47.19 & 234.76 & 339.56 & 10.63 & 22.89 \\
\hline Sirmaur & 13.26 & 14.88 & 5.56 & 20.10 & 0.38 & 0.43 \\
\hline Solan & 10.92 & 6.15 & 4.57 & 8.78 & 0.42 & 1.43 \\
\hline Una & 4.00 & 5.92 & 3.18 & 17.93 & 0.80 & 3.02 \\
\hline H P & 163.52 & 228.95 & 396.20 & 702.00 & 2.44 & 3.07 \\
\hline
\end{tabular}

Source: Directorate of Land Records, Shimla 
Table.6 Area, production and productivity of vegetables (2001-02to 2017-18)

\begin{tabular}{|l|c|c|c|c|c|c|}
\hline \multirow{2}{*}{} & \multicolumn{2}{|c|}{ Area ('000 ha) } & \multicolumn{2}{c|}{ Production ('000 Metric tonnes) } & \multicolumn{2}{c|}{ Productivity (t/ha) } \\
\cline { 2 - 7 } & TE 2001-02 & TE 2017-18 & TE 2001-02 & TE 2017-18 & TE 2001-02 & TE 2017-18 \\
\hline Bilaspur & 1.63 & 3.12 & 28.01 & 85.15 & 17.15 & 27.26 \\
\hline Chamba & 1.317 & 3.31 & 18.93 & 65.03 & 14.38 & 19.61 \\
\hline Hamirpur & 0.89 & 3.83 & 13.82 & 59.86 & 15.53 & 15.64 \\
\hline Kangra & 2.65 & 8.20 & 43.35 & 178.63 & 16.36 & 21.78 \\
\hline Kinnaur & 0.95 & 3.66 & 11.67 & 45.63 & 12.23 & 12.45 \\
\hline Kullu & 3.01 & 6.19 & 59.42 & 133.94 & 19.74 & 21.65 \\
\hline Lahaul \& Spiti & 1.77 & 4.36 & 18.83 & 57.31 & 10.65 & 13.14 \\
\hline Mandi & 3.33 & 11.01 & 49.24 & 222.44 & 14.80 & 20.21 \\
\hline Shimla & 5.95 & 12.67 & 98.46 & 231.57 & 16.55 & 18.27 \\
\hline Sirmaur & 4.15 & 8.86 & 84.78 & 201.31 & 20.42 & 22.73 \\
\hline Solan & 5.41 & 9.64 & 131.35 & 333.91 & 24.29 & 34.63 \\
\hline Una & 0.99 & 2.09 & 17.94 & 36.43 & 18.13 & 17.45 \\
\hline HP & 32.05 & 76.95 & 575.81 & 1651.21 & 17.97 & 21.46 \\
\hline SO
\end{tabular}

Source: Directorate ofHorticulture, Shimla

Table.7 District wise CAGR and CV of cereals (1991-92 to 2017-18) (Per cent)

\begin{tabular}{|l|c|c|c|c|c|c|}
\hline \multirow{2}{*}{ Districts } & \multicolumn{2}{|c|}{ Area } & \multicolumn{2}{c|}{ Production } & \multicolumn{2}{c|}{ Productivity } \\
\cline { 2 - 7 } & CAGR & CV & CAGR & CV & CAGR & CV \\
\hline Bilaspur & $-0.50^{*}$ & 5.12 & 0.17 & 21.44 & 0.68 & 21.15 \\
\hline Chamba & -0.03 & 4.87 & 0.62 & 19.87 & 0.64 & 20.68 \\
\hline Hamirpur & $-0.54^{*}$ & 4.50 & -0.34 & 16.48 & 0.20 & 16.17 \\
\hline Kangra & -0.05 & 3.96 & 0.57 & 14.50 & 0.62 & 16.03 \\
\hline Kinnaur & $-4.00^{*}$ & 31.90 & $-3.75^{*}$ & 31.34 & 0.26 & 23.13 \\
\hline Kullu & -0.32 & 8.87 & 0.16 & 16.57 & 0.48 & 17.46 \\
\hline Lahaul \& Spiti & $-3.53^{*}$ & 28.35 & $-7.16^{*}$ & 117.39 & $-3.76^{*}$ & 91.51 \\
\hline Mandi & $-0.49^{*}$ & 4.17 & $-3.03^{*}$ & 28.28 & $-2.55^{*}$ & 26.40 \\
\hline Shimla & $-3.86^{*}$ & 32.02 & $-2.88^{*}$ & 28.62 & $1.02^{*}$ & 16.39 \\
\hline Sirmaur & $-0.74^{*}$ & 7.47 & -0.47 & 13.25 & 0.27 & 13.47 \\
\hline Solan & -0.09 & 5.96 & 0.77 & 17.79 & 0.86 & 18.55 \\
\hline Una & 0.001 & 4.77 & 0.45 & 17.62 & 0.45 & 17.51 \\
\hline HP & $-0.51^{*}$ & 4.49 & -0.12 & 10.90 & 0.39 & 11.97 \\
\hline
\end{tabular}

Note $=* 1 \%$ level of significance, $* * 5 \%$ level of significance 
Table.8 District wise CAGR and CV of pulses (1991-92 to 2017-18) (Per cent)

\begin{tabular}{|l|c|c|c|c|c|c|}
\hline \multirow{2}{*}{ Districts } & \multicolumn{2}{|c|}{ Area } & \multicolumn{2}{c|}{ Production } & \multicolumn{2}{c|}{ Productivity } \\
\cline { 2 - 7 } & CAGR & CV & CAGR & CV & CAGR & CV \\
\hline Bilaspur & $-9.39^{*}$ & 111.55 & $-7.61^{*}$ & 76.66 & 1.96 & 42.40 \\
\hline Chamba & -0.36 & 13.49 & $3.97^{* *}$ & 122.07 & $4.35^{*}$ & 103.78 \\
\hline Hamirpur & $-15.25^{*}$ & 119.77 & $-16.40^{*}$ & 129.67 & $-1.36^{* *}$ & 24.89 \\
\hline Kangra & $-1.95^{*}$ & 20.49 & 1.07 & 76.32 & $3.08^{*}$ & 72.69 \\
\hline Kinnaur & $-9.98^{*}$ & 54.58 & -7.61 & 68.74 & 2.63 & 59.58 \\
\hline Kullu & $-2.00^{* *}$ & 24.92 & 2.34 & 111.88 & $3.00^{* *}$ & 99.30 \\
\hline Lahaul \& Spiti & $-7.91^{*}$ & 73.24 & - & 111.88 & - & 84.07 \\
\hline Mandi & -0.77 & 33.69 & $3.12^{* *}$ & 77.08 & $3.92^{*}$ & 62.59 \\
\hline Shimla & $-1.80^{*}$ & 23.22 & $3.91^{*}$ & 84.81 & $5.82^{*}$ & 84.27 \\
\hline Sirmaur & $-1.53^{*}$ & 19.95 & 2.63 & 77.91 & $4.23^{*}$ & 67.95 \\
\hline Solan & $-4.97^{*}$ & 38.99 & $-4.55^{*}$ & 49.17 & 0.44 & 49.11 \\
\hline Una & $-8.98^{*}$ & 66.35 & $-6.60^{*}$ & 58.25 & $2.61^{*}$ & 32.15 \\
\hline HP & $-2.25^{*}$ & 21.59 & 0.68 & 59.85 & $3.00^{*}$ & 60.92 \\
\hline
\end{tabular}

Note $=* 1 \%$ level of significance, $* * 5 \%$ level of significance

Table.9 District wise CAGR and CV of fruits (1991-92 to 2017-18) (Per cent)

\begin{tabular}{|l|c|c|c|c|c|c|}
\hline \multirow{2}{*}{ Districts } & \multicolumn{2}{|c|}{ Area } & \multicolumn{2}{c|}{ Production } & \multicolumn{2}{c|}{ Productivity } \\
\cline { 2 - 7 } & CAGR & CV & CAGR & CV & CAGR & CV \\
\hline Bilaspur & -0.003 & 11.37 & $7.97^{*}$ & 68.02 & $7.97^{*}$ & 68.31 \\
\hline Chamba & $2.13^{*}$ & 22.94 & $6.47^{*}$ & 73.19 & $4.25^{*}$ & 64.33 \\
\hline Hamirpur & $1.55^{*}$ & 16.00 & $9.90^{*}$ & 66.18 & $8.22^{*}$ & 64.99 \\
\hline Kangra & -0.05 & 7.19 & $6.70^{*}$ & 56.55 & $6.76^{*}$ & 60.40 \\
\hline Kinnaur & $3.54^{*}$ & 33.04 & $6.41^{*}$ & 48.45 & $2.77^{*}$ & 29.55 \\
\hline Kullu & $1.69^{*}$ & 21.71 & $3.38^{* *}$ & 49.96 & 1.66 & 48.02 \\
\hline LahaulSpiti & $8.72^{*}$ & 64.50 & $7.21^{*}$ & 67.17 & -1.39 & 57.72 \\
\hline Mandi & $1.37^{*}$ & 14.01 & $5.71^{*}$ & 59.41 & $4.27^{*}$ & 53.88 \\
\hline Shimla & $-4.30^{*}$ & 35.96 & $4.15^{*}$ & 49.86 & $8.82^{*}$ & 89.25 \\
\hline Sirmaur & $5.63^{*}$ & 62.01 & $8.04^{*}$ & 58.75 & 2.28 & 70.53 \\
\hline Solan & $-3.37^{*}$ & 33.24 & $7.19^{*}$ & 54.14 & $10.92^{*}$ & 69.20 \\
\hline Una & $0.90^{*}$ & 8.81 & $7.69^{*}$ & 64.62 & $6.72^{*}$ & 57.72 \\
\hline HP & $0.93^{*}$ & 12.62 & $4.49^{*}$ & 45.53 & $3.53^{*}$ & 44.02 \\
\hline
\end{tabular}

Note $=* 1 \%$ level of significance, $* * 5 \%$ level of significance 
Table.10 District wise CAGR and CV of vegetables (1995-96 to 2017-18) (Per cent)

\begin{tabular}{|l|c|c|c|c|c|c|}
\hline \multirow{2}{*}{ Districts } & \multicolumn{2}{|c|}{ Area } & \multicolumn{2}{c|}{ Production } & \multicolumn{2}{c|}{ Productivity } \\
\cline { 2 - 7 } & CAGR & CV & CAGR & CV & CAGR & CV \\
\hline Bilaspur & $5.18^{*}$ & 30.12 & $7.06^{*}$ & 41.84 & $1.79^{* *}$ & 27.87 \\
\hline Chamba & $6.46^{*}$ & 39.19 & $7.66^{*}$ & 49.16 & 1.13 & 18.05 \\
\hline Hamirpur & $11.68^{*}$ & 60.82 & $9.52^{*}$ & 140.93 & -1.94 & 150.37 \\
\hline Kangra & $7.49^{*}$ & 42.48 & $9.08^{*}$ & 49.91 & $1.48^{*}$ & 12.25 \\
\hline Kinnaur & $9.64^{*}$ & 50.04 & $10.55^{*}$ & 56.11 & $0.83^{*}$ & 13.28 \\
\hline Kullu & $5.46^{* *}$ & 197.96 & $5.70^{*}$ & 37.17 & 0.22 & 24.08 \\
\hline Lahaul \& Spiti & $7.28^{*}$ & 40.25 & $8.43^{*}$ & 45.48 & $1.07 *$ & 12.31 \\
\hline Mandi & $6.96^{*}$ & 44.08 & $9.44^{*}$ & 56.94 & $2.32^{*}$ & 17.10 \\
\hline Shimla & $4.29^{*}$ & 31.46 & $6.41^{*}$ & 37.58 & $2.03^{*}$ & 16.60 \\
\hline Sirmaur & $5.12^{*}$ & 31.47 & $5.96^{*}$ & 38.00 & $0.80^{*}$ & 8.68 \\
\hline Solan & $4.77^{*}$ & 29.04 & $6.75^{*}$ & 42.08 & $1.89^{*}$ & 18.64 \\
\hline Una & $4.43^{*}$ & 30.33 & $3.73^{*}$ & 26.28 & -0.67 & 13.05 \\
\hline HP & $5.59^{*}$ & 34.59 & $7.16^{*}$ & 42.65 & $1.49 *$ & 11.39 \\
\hline
\end{tabular}

Note $=* 1 \%$ level of significance, $* * 5 \%$ level of significance

The detail of the annual growth in area, production and productivity of pulses is presented in Table 8. The area under pulses in the state has shown a significant decrease ($2.25 \%)$. Among districts, the growth rate is decreasing and significant Hamirpur (15.25\%) followed by Kinnaur (-9.98\%), Bilaspur ($9.39 \%)$ and Una $(-8.98 \%)$ during the study period. There is a mild fluctuation in the area of the pulses in the state $(21.59 \%)$. The growth in pulses production in the state positive but nonsignificant was $0.68 \%$ with fluctuation of 59.85 $\%$. The growth rate of productivity of the pulses was positive and significant $(3.00 \%)$. This growth may be due to the increase in the research work of the state and the introduction of the high yielding varieties. Shimla has shown a maximum annual significant increase in the productivity of the pulses i.e. $5.82 \%$ followed by Chamba (4.35\%) and Sirmaur (4.23\%).

Table 9 represents the growth trend in the area, production, and productivity of the total fruits. The area and production of the fruits have shown a positive and significant growth rate of $0.93 \%$ and $4.49 \%$ respectively. This increment in the area of the fruits again symbolises the shift in the production pattern towards the high- value commodities. The annual growth rate of the production of fruits is positive and significant for all the districts ranging from 3.38 $\%$ to $9.90 \%$, maximum being in Hamirpur. The productivity of the fruits has shown positive significant growth rate for almost all the districts except for Lahaul \& Spiti (-1.39 \%). Table 10 presents the significant and positive growth in the area and production of vegetables in the state and all the districts. The area under the vegetables in the state has registered a positive and significant annual growth rate of $5.59 \%$ during the study period. The increment was highest for the district Hamirpur (11.68\%), Kinnaur $(9.64 \%)$ and Lahaul \& Spiti (7.28 \%). The variation in the area of the vegetables for the state is $34.59 \%$. Theannual growth in the production of the vegetables was $10.55 \%$ in Kinnaur, followed by Hamirpur (9.52 \%), Mandi (9.44 \%) and Kangra (9.08\%), whereas in the state it has shown a growth rate of $7.16 \%$ per annum. The productivity of the vegetables has also registered a positive growth rate in almost all the districts except for Hamirpur ($1.94 \%)$ and Una (-.067 \%) where it declined.

In conclusion the agricultural in Himachal Pradesh has transformed from foodgrains 
towards non-foodgrains production as a shift can be seen in the change in cropping pattern over three decades. The analysis showed that this sector has made reasonably good growth over the years as can be witnessed from the increase in cereals production from 12.64 lakh tonnes to 13.67 tonnes from 1991-92 to $2017-18$ and pulses production from 0.12 lakh tonnes to 0.41 Lakh tonnes despite the decline in the area under these crops. The yield of all the crops increased in all the districts at varying degrees. Agriculture has diversified from the cereal crops towards high-value commodities; thus, the horticulture sector also registered a significant increase in terms of vegetables including off-season crops (pea, cauliflower, cabbage, etc) and fruits production. Considerably better performance of the agriculture sector in the state became possible because of the flourishing horticultural sector. The crop diversification was most prominent in the districts which have favourable agroclimatic conditions for the cultivation of these crops as the shift can be seen in the gross cropped area under high-value commodities in these districts. Since high-value crops generate better returns and land productivity also increases with the increased diversification, thus this would help to boost the economy of the state.

\section{References}

Anonymous, 2020, Economic Survey 2019-20. Directorate of Economics and Statistics, Shimla, Himachal Pradesh.

Directorate of Land Records. Annual Season and Crop Report, various issues, Directorate of Land Records, Shimla, Himachal Pradesh.

Kumar S., and Gupta S. (2015). Crop Diversification Towards High-Value Crops in India: A State-Level Empirical Analysis. Agricultural Economics
Research Review, 28(2), 339-350.

Kumari, S. (2007). High-Value Cash Crops Agriculture in Himachal Pradesh: A Study in Documentation and Valuation of Environmental Cost. Ph D Thesis, CSK HPKV, Palampur, Himachal Pradesh.

Lathika, M. and Kumar, C.E.A. (2005). Growth Trends in Area, Production and Productivity of Coconut in India. Indian Journal of Agricultural Economics,60(4), 686- 697.

Nayak, D.K. 2016. Changing Cropping Pattern, Agricultural Diversification and Productivity in Odisha - A District-Wise Study. Agricultural Economics Research Review, 29(1),93-104.

Rao, P.P., Birthal, P.S.,\& Joshi, P.K. (2006). Diversification Towards High Value Agriculture: Role of Urbanisation and Infrastructure. Economic \& Political Weekly 41(26): 2747-2753.

Sharma, H.R. (2005). Agricultural Development and Crop Diversification in Himachal Pradesh: Understanding the Patterns, Processes, Determinants and Lessons. Indian Journal of Agricultural Economics, 60(1), 71-92.

Sharma, H.R. (2011). Crop Diversification in Himachal Pradesh: Pattern, Determinants and Challenges. Indian Journal of Agricultural Economics, 66(1), 97-114.

Sharma, H.R., and Chauhan, S.K. (2008). Diversification in Agriculture in Himachal Pradesh: A Success Story. Indian Farming, 58(4), 12-14.

Thakur, B.R., Sharma, D. D. and Mohan, P. (2014). Dynamics of agricultural production. In: Singh, R. Hietala, R. (Eds.), Livelihood security in Northwestern Himalaya. Advances in geographical and environmental sciences. (pp. 67-82).Tokyo, Springer.

\section{How to cite this article:}

Jyoti Chaudhary and Singh, H. P. 2020. Diversification of Agricultural Crops in Himachal Pradesh: A Shift towards High-Value Crops. Int.J.Curr.Microbiol.App.Sci. 9(12): 2224-2235. doi: https://doi.org/10.20546/ijcmas.2020.912.262 